\title{
Penyelesaian Perkara Kepailitan Dengan Harta Pailit Berada Di Luar Negeri
}

\author{
I Dewa Made Adhi Hutama1 , Dewa Gde Rudy²
}

${ }^{1}$ Fakultas Hukum Universitas Udayana, E-mail: adhihutamadewa@gmail.com

${ }^{2}$ Fakultas Hukum Universitas Udayana, E-mail: dewa_rudy@unud.ac.id

\begin{abstract}
Info Artikel
Masuk: 1 Januari 2020

Diterima : 14 Mei 2020

Terbit : 28 Agustus 2020

Keywords :

Bankruptcy; Bankruptcy

Property; Overseas

Kata kunci:

Kepailitan; Harta Pailit; Luar

Negeri

Corresponding Author:

I Dewa Made Adhi Hutama,

E-mail:

adhihutamadewa@gmail.com

DOI :

10.24843/AC.2020.v05.i02.p12
\end{abstract}

\begin{abstract}
Bankruptcy is an effort made as a form of efforts to protect the rights of creditors when the debtor is no longer able to pay off his debt. In bankruptcy proceedings it is possible for bankrupt debtors to have assets that are abroad that were not previously used as collateral. With this situation, problems will arise regarding how Indonesian law regulates bankruptcy of foreign debtors' assets abroad. and what legal remedies can be taken so that bankrupt creditors can get paid off with the assets of bankrupt debtors abroad? This research will be conducted using the normative juridical method by examining library materials related to this research, as well as carried out with the statutory approach and conceptual approach. In the Civil Code and the Bankruptcy and Delay Obligation of Debt Payment obligations, it does not clearly regulate the debtor's assets abroad, but in several articles it shows that it is possible to make the assets used for bankruptcy. There are efforts that can be made so that the assets of bankrupt debtors abroad can be executed as repayment of their debts by submitting an application through a court in the country where the debtor's assets are located, through bilateral agreements, diplomatic channels, and using the UNCITRAL Model Law on Cross Border Insolvency with Guide to Enacment. Based on Indonesian law, debtor assets abroad are possible as a means of paying off debts with certain efforts, but it will be easier to ratify the UNCITRAL Model Law on Cross Border Insolvency with Guide to Enacment.
\end{abstract}

\begin{tabular}{l}
\hline Abstrak \\
\hline Kepailitan merupakan suatu tindakan yang dilakukan sebagai \\
wujud upaya perlindungan hak kreditor pada saat debitor sudah \\
tidak mampu lagi melunasi hutangnya. Di dalam perkara \\
kepailitan dimungkinkan debitor pailit memiliki harta yang \\
berada di luar negeri yang sebelumnya tidak digunakan sebagai \\
jaminan. Berdasarkan hal tersebut, maka ada 2 permasalahan \\
yang akan dijawab dalam penelitian ini, yaitu: (1) bagaimana \\
hukum Indonesia mengatur mengenai harta debitor pailit yang \\
berada di luar negeri ? dan (2) upaya hukum apa yang dapat \\
dilakukan sehingga kreditor pailit dapat memperoleh pelunasan \\
dengan harta debitor pailit yang berada di luar negeri? \\
Penelitian ini tergolong jenis penelitian yuridis normatif yang
\end{tabular}




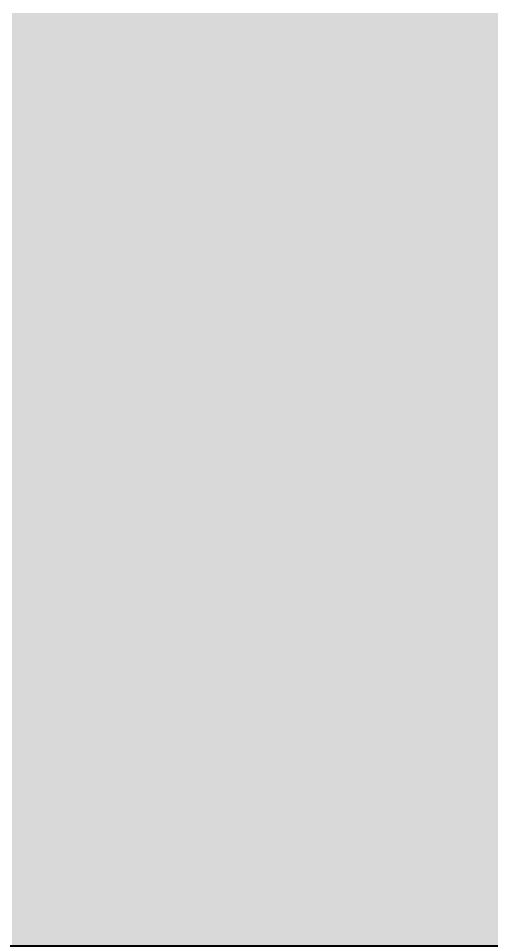

menggunakan 2 jenis pendekatan, yaitu : (1) pendekatan perundang-undangan; dan (2) pendekatan konsep. Berdasarkan hasil penelitian, diperoleh kesimpulan sebagai beikut: (1) Hukum di Indonesia, baik Kitab Undang-Undang Hukum Perdata maupun Undang-Undang Kepailitan dan Penundaan Kewajiban Pembayaran Utang tidak secara jelas mengatur secara jelas mengenai harta debitor yang berada di luar negeri. Namun demikian ditemui beberapa pasal dalam 2 peraturan perundang-undangan sebagaimana dimaksud di atas yang memberikan peluang bahwa harta tersebut dijadikan boedel pailit; (2) Upaya yang dapat dilakukan agar harta debitor pailit di luar negeri bisa dieksekusi sebagai pelunasan hutangnya iialah dengan cara mengajukan permohonan melalui pengadilan yang ada dinegara letak harta benda debitor, melalui bilateral agreement, diplomatic channel, dan menggunakan UNCITRAL Model Law on Cross Border Insolvency with Guide to Enacment. Berdasarkan hukum di Indonesia, terhadap harta debitor yang ada di luar negeri dimungkinkan sebagai alat pelunasan hutang dengan upaya-upaya tertentu, namun akan lebih mudah dengan meratifikasi UNCITRAL Model Law on Cross Border Insolvency with Guide to Enacment.

\section{Pendahuluan}

Keadaan di mana seseorang yang memiliki hutang dan tidak mampu membayar hutang-hutangnya akan menempatkan seseorang dalam keadaan pailit. Setelah seseorang berada pada keadaan pailit, maka akan dilanjutkan dengan proses kepailitan sebagai salah satu upaya dalam penyelesaian utang debitor pailit. Kepailitan didefinisikan menurut Undang-Undang Nomor 37 Tahun 2004 tentang Kepailitan dan Penundaan Kewajiban Pembayaran Utang, Lembaran Negara Republik Indonesia Tahun 2004 Nomor 131, Tambahan Lembaran Negara Republik Indonesia Nomor 4443 (selanjutnya disebut UUK-PKPU) sebagai sita atas semua kekayaan yang pada saat itu dimiliki oleh debitor yang telah diputus pailit, yang mana pengurusan serta penyelesainnya dilakukan Kurator yang mana pelaksanaan diawasi oleh Hakim Pengawas. Kepailitan adalah langkah untuk menjamin kreditor guna memperoleh pembagian atas harta yang dimiliki debitor pailit. ${ }^{1}$ Lahirnya UUK PKPU sebagai suatu usaha dalam penyelesaian perkara kepailitan di pengadilan, bukan bentuk cara terakhir mengenai penyelesaian hutang itu sendiri. ${ }^{2}$

Pada setiap kegiatan utang piutang tentu memerlukan adanya jaminan yang memberikan rasa aman bagi kreditor sehingga ia mau meminjamkan uangnya. Benda yang dapat digunakan sebagai jaminan merupakan benda-benda yang berharga dan nilainya lebih tinggi dari nilai hutang yang dimiliki debitor. Pada umumnya, yang digunakan sebagai jaminan oleh yakni emas, tanah, kendaraan bermotor dan saat ini

1 Asnil, D. M. (2018). UNCITRAL Model Law on Cross Border Insolvency Sebagai Model Pengaturan Kepailitan Lintas Batas Indonesia dalam Integrasi Ekonomi ASEAN. Undang: Jurnal Hukum, 1(2), 323-346.

2 Wijayanta, T. (2014). Asas Kepastian Hukum, Keadilan dan Kemanfaatan dalam Kaitannya dengan Putusan Kepailitan Pengadilan Niaga. Jurnal Dinamika Hukum, 14(2), 216-226. 
bentuk dari jaminan telah berkembang seperti merk ataupun saham. Selain dari bentuk, letak benda jaminan juga telah mengalami perkembangan. Yang mana letak telah berkembang tidak hanya berada di suatu wilayah atau negara saja, dimungkinkan juga berada di wilayah atau di negara lain.

Salah satu faktor pendorong perkembangan letak harta benda yang dimiliki seseorang yakni mudahnya akses serta perkembangan bisnis ditingkat internasional. Perkembangan teknologi merupakan salah satu penyebab banyak orang yang melakukan transaksi lintas batas, karena hal ini akan mempermudah seseorang memantau bisnis diluar jangkauan fisiknya dan mempermudah memperoleh informasi mengenai perkembangan bisnis. Tidak jarang orang yang melakukan bisnis lintas batas memperoleh modal usahanya dari aktivitas utang piutang. Namun saat ini tidak banyak kreditor yang mau meminjamkan uang dengan jaminan harta benda yang diluar yurisdiksinya.

Pada setiap kegiatan utang piutang, selain adanya jaminan tentu saja ada jangka waktu yang diberikan kreditor kepada debitornya. Apabila pihak debitor tidak dapat memenuhi pretasinya berdasarkan jangka waktu yang disepakati dan debitor dalam keadaan tidak memiliki kemampuan lagi dalam pemenuhan prestasinya maka baik dari pihak debitor sendiri maupun dari pihak kreditor-kreditornya dapat mengajukan pailit kepada Pengadilan Niaga. Merujuk pada definisi kepailitan, maka dalam proses kepailitan akan dilakukan penyitaan atas seluruh harta kebendaan yang pada saat itu dimiliki oleh pihak debitor yang sudah diputus pailit dan keseluruhan harta akan dikumpulkan dan diurus oleh pihak yang diberikan kewenangan yakni kurator dengan adanya pengawasan yang dilaksanakan oleh Hakim Pengawas, serta harta itu akan digunakan oleh kreditor-kreditornya sebagai alat pelunasan piutang. ${ }^{3}$

Pelaksanaan dari proses kepailiatan adalah upaya dari pelaksanaan sesuai dengan ketentuan yang ada pada KUHPdt yang secara khusus ditentukan pada Pasal 1131 yang menyebutkan yakni atas kesemua harta benda yang menjadi kepunyaan dari debitor pailit yang sifatnya sebagai benda bergerak maupun memiliki sifat sebagai benda tidak bergerak, yang mana telah ada ataupun yang mungkin ada di kemudian hari akan menjadi tanggungan atas segala bentuk perikatan yang bersifat perseorangan. Khusus pada ketentuan dalam Pasal 1131 dan Pasal 1132 dijadikan sebagai kepastian secara hukum bagi pihak kreditor untuk memperoleh apa yang menjadi hak atas pelunasan piutang miliknya. ${ }^{4}$ Ketentuan ini juga didukung dengan adanya prinsip dalam UUK PKPU yang menentukan bahwa atas setiap hutang milik seorang debitor akan selalu mengikuti dan baru hanya akan berhenti apabila atas hutang tersebut telah di bayar lunas. Secara khusus pada Pasal 21 UUK PKPU menyebutkan bahwa kepailitan adalah suatu proses penyelesaian yang menggunakan keseluruhan atas harta yang pada saat diucapkan pailit dimiliki oleh debitor maupun akan sesuatu yang dimungkinkan diperoleh dikemudian hari selama proses kepailitan berlangsung. Secara tidak langsung ketentuan di dalam UUK PKPU mencakup atas

3 Retnaningsih, S. (2018). Perlindungan Hukum Terhadap Debitor Pailit Individu Dalam Penyelesaian Perkara Kepailitan Di Indonesia. ADHAPER: Jurnal Hukum Acara Perdata, 3(1), 1-16.

${ }^{4}$ Makmur, S. (2018). Kepastian Hukum Kepailitan Bagi Kreditur dan Debitur Pada Pengadilan Niaga Indonesia. Mizan: Journal of Islamic Law, 4(2). 
keseluruhan harta yang sifatnya tidak terbatas dari wilayah, termasuk atas harta di luar negeri yang mana artinya pada ketentuan ini menganut asas universalitas. ${ }^{5}$

Keberlakuan ketentuan dalam KUHPdt dan UUK PKPU merupakan wujud perlindungan bagi kreditor agar seimbang dengan prestasi yang sudah ia lakukan kepada debitor. ${ }^{6}$ Baik di dalam KUHPdt dan di dalam UUK PKPU tidak secara tegas menentukan keberlakuan atas sita kekayaan yang dimiliki, hanya saja ketentuan yang diatur dalam kedua produk hukum tersebut memungkinkan melakukan penyitaan terhadap harta yang telaknya ada di luar yurisdik suatu negara, khususnya di luar Indonesia. Namun dalam kenyataannya, tidak akan mudah melakukan sita terhadap harta kekayaan seorang debitor yang telah pailit yang letaknya ada di luar negeri dan menggunakan harta tersebut sebagai boedel pailit. Dapat dikatakan bahwa kepailitan dengan harta pailit diluar negeri merupakan bentuk dari kepailitan lintas batas karena terdapat beberapa unsur asing di dalamnya. Setiap negara yang memiliki hukum kepailitan tentu akan menerapkan hukum positif negaranya, namun dalam kepailitan lintas batas terdapat lebih dari satu hukum kepailitan yang menjadi variabel. ${ }^{7}$

Hal ini terjadi karena setiap negara tentu memiliki kedaulatan yang perlu dihormati selain juga mengingat setiap negara memiliki asas yang dianut. Terdapat beberapa negara yang menganut asas universal, yang artinya negara tersebut mau mengakui putusan pengadilan negara lain dan dapat digunakan atau dilaksanakan di negaranya. Selain itu beberapa negara juga menganut asas teritorial, yang mana berdasarkan asas tersebut maka negara tidak mengakui dan tidak dapat melaksanakan atas putusan pengadilan negara asing di negaranya. Oleh sebab itu, apabila seorang debitor pailit memiliki harta benda berada di luar negeri, maka belum tentu atas benda tersebut dapat digunakan sebagai alat pelunasan utang.

Terdapat beberapa karya ilmiah yang membahas mengenai kepailitan, khususnya kepailitan lintas batas. Seperti karya ilmiah oleh Loura Hardjaloka yang mengangkat judul, "Kepailitan Lintas Batas Perspektif Hukum Internasional dan Perbandingan dengan Instrumen Nasional di Beberapa Negara". Penelitian ini lebih membahas mengenai perkembangan hukum dalam penyelesaian kepailitan lintas batas, dan menyimpulkan bahwa Indonesia masih harus melakukan upaya penyelesaian seperti yang dilakukan oleh negara lain sehingga mempermudah dalam penyelesaian perkara kepailitan. Penyelesaian perkara kepailitan lintas batas dalam penelitian tersebut disimpulkan akan lebih mudah dilakukan dengan melakukan perjanjian bilateral atau multilateral atau dengan meratifikasi aturan-aturan hukum internasional. ${ }^{8}$ Selain itu terdapat karya ilmiah yang ditulis oleh Jihan Amalia dengan judul, "Urgensi Implementasi UNCITRAL Model Law on Cross-Border Insolvency di Indonesia: Studi

5 Hardjaloka, L. (2015). Kepailitan Lintas Batas Perspektif Hukum Internasional Dan Perbandingannya Dengan Instrumen Nasional Di Beberapa Negara. Yuridika, 30(3), 480-504.

6 Budiono, D. (2019). Analisis Pengaturan Hukum Acara Kepailitan dan Penundaan Kewajiban Pembayaran Utang. Jurnal Hukum Acara Perdata ADHAPER, 4(2), 109-127.

7 Amalia, J. (2019). URGENSI IMPLEMENTASI UNCITRAL MODEL LAW ON CROSSBORDER INSOLVENCY DI INDONESIA: STUDI KOMPARASI HUKUM KEPAILITAN LINTAS BATAS INDONESIA DAN SINGAPURA. Jurnal Hukum Bisnis Bonum Commune, 2(2), 162-172.

8 Hardjaloka, L. (2015). Kepailitan Lintas Batas Perspektif Hukum Internasional dan Perbandingannya Dengan Instrumen Nasional di Beberapa Negara. Yuridika, 30(3), 480-504. 
Komparasi Hukum Kepailitan Lintas Batas Indonesia dan Singapura". Pada penelitian tersebut lebih menjelaskan mengenai Indonesia dan Singapura yang belum memiliki aturan hukum yang mampu menyelesaikan perkara kepailitan yang sifatnya lintas batas negara, sehingga diharapkan adanya terobosan dengan menerapkan UNCITRAL Model Law on Cross-Border Insolvency. ${ }^{9}$

Penelitian dalam penulisan karya ilmiah ini, lebih memfokuskan mengenai penyelesaian kepailitan dengan harta yang dimiliki oleh debitor pailit berada di luar negeri. Memfokuskan mengenai tindakan hukum yang dapat dilakukan sehingga apa yang menjadi hak dari kreditor dapat terpenuhi, meskipun letak boedel pailitnya tidak berada di Indonesia. Bagaimana pun terhadap perkara yang melibatkan negara lain, tentu saja memerlukan bantuan dari negara tempat diajukannya perkara kepailitan guna perkara tersebut dapat diselesaikan dengan baik. Agar salah satu tujuan hukum yakni keadilan dan kepastian hukum mampu terpenuhi sebagaimana mestinya.

Berdasarkan uraian tersebut, maka dapat dirumuskan 2 permasalahan hukum yaitu; (1) bagaimana hukum Indonesia mengatur mengenai harta debitor pailit yang berada di luar negeri? ; dan (2) upaya hukum apa yang dapat dilakukan sehingga kreditor pailit dapat memperoleh pelunasan dengan harta debitor pailit yang berada di luar negeri? Dengan rumusan masalah tersebut maka peneliti tertarik untuk melakukan penelitian dengan menggunakan judul, "Penyelesaian Perkara Kepailitan dengan Harta Pailit Berada di Luar Negeri".

\section{Metode Penelitian}

Penelitian yang dilakukan didasarkan pada penelitian yuridis normatif yang mana penelitian ini akan dilakukan dalam memperoleh informasi terkait digunakan bahan hukum yang diperoleh dengan metode kepustakaan seperti peraturan perundangundangan, buku, serta kamus dan ensiklopedi. Dilakukannya pendekatan tentu memiliki tujuan yang mana dimaksudkan agar peneliti memperoleh informasi dair berbagai aspek yang relevan dengan yang akan diteliti. ${ }^{10}$ Penelitian ini akan memfokuskan menggunakan pendekatan perundang-undangan dan pendekatan konseptual. Bahan hukum yang akan digunakan oleh peneliti yakni bahan hukum primer, sekunder dan tertier. Bahan hukum primer yang digunakan yaitu KUHPdt dan UUK PKPU. Untuk bahan hukum sekunder yang menjadi pendukung yakni buku, hasil karya ilmiah maupun pendapat para ahli. Sedangkan untuk bahan hukum tertier akan digunakan agar mendapatkan penjelasan mengenai bahan hukum yang terlah diperoleh akan digunakan kamus dan juga ensiklopedi. Mengenai teknik dari pengumpulan bahan hukum yang diperoleh akan dilakukan dengan metode pencatatan bahan yang secara sistematis dan teknik analisis yang diterapkan yakni deskripsi, sistematisasi, interprestasi, dan argumentasi.

\footnotetext{
9 Amalia, J. (2019). URGENSI IMPLEMENTASI UNCITRAL MODEL LAW ON CROSSBORDER INSOLVENCY DI INDONESIA: STUDI KOMPARASI HUKUM KEPAILITAN LINTAS BATAS INDONESIA DAN SINGAPURA. Jurnal Hukum Bisnis Bonum Commune, 2(2), 162-172.

${ }^{10}$ Marzuki, P.M, 2013, Penelitian Hukum, Kencana Prenada Media Group, Jakarta, h. 133.
} 


\section{Hasil Dan Pembahasan}

\subsection{Pengaturan Hukum Kepailitan Indonesia Mengenai Harta Debitor Pailit di Luar Negeri}

Menurut hukum kepailitan yang berlaku di Indonesia, harta yang dimiliki oleh seorang debitor yang telah dinyatakan pailit yang dimiliki olehnya pada saat ia diputus pailit serta kemungkinan harta yang akan diperolehnya selama kepailitan dapat dikategorikan sebagai boedel pailit. Pada BAB II khususnya Bagian Kedua pada UUK PKPU telah menentukan bahwa adanya akibat hukum bagi harta benda debitor yang ia miliki pada saat putusan pailit diucapkan. Cakupan keberlakuan ketentuan tersebut tidak memiliki batasan, termasuk batasan mengenai keberlakuan ketentuan tersebut. Ditentukan secara implisit pada ketentuan Pasal 212 hingga Pasal 214 UUK PKPU bahwa harta benda yang dimiliki debitor yang dikategorikan pailit yang letaknya ada di luar lingkup wilayahnya (luar negeri) dapat digunakan sebagai alat pelunasan hutang debitor.

Berdasarkan ketentuan pada Pasal 212 UUK PKPU terlihat bahwa harta benda yang dimiliki oleh seorang debitor yang telah pailit yang mana keberadaan benda tersebut diberada di luar negeri dapat digunakan sebagai boedel pailit. Mengacu pada ketentuan pasal tersebut maka menunjukkan diberikannya kesempatan bagi kreditor-kreditor dari debitor pailit untuk memperoleh pelunasan atas piutangnya dengan harta benda yang dimiliki oleh debitor tersebut yang letaknya ada di luar negeri. Namun agar pasal ini dapat diberlakukan, maka pihak kreditor yang mengetahui serta mampu membuktikan bahwa memang benar debitornya memiliki harta benda di luar negeri, maka ia dapat mengajukan melalui pengadilan sehingga harta tersebut dapat digunakan sebagai pelunasan. Keberlakukan atas pasal tersebut hanya bisa berlaku apabila debitornya telah diputus pailit oleh pengadilan Niaga, kreditor-kreditornya telah memperoleh pelunasan berdasarkan hasil penjualan barang yang dimiliki oleh debitor baik terhadap seluruh ataupun sebagian atas piutangnya, harta benda debitor benar berada di luar negeri, serta pihak kreditor bukan kreditor preferen terhadap harta benda tersebut, yang artinya kreditor bukan seorang pemegang hak jaminan atas benda tersebut. ${ }^{11}$

Ketentuan dalam Pasal 213 ayat (1) UUK PKPU selanjutnya menentukan bahwa keberlakuan Pasal 212 memiliki akibat hukum yakni adanya kewajiban agar mengganti atas harta debitor pailit yakni sesuai dengan pelunasan yang didapatkan oleh pihak kreditor sebagai penerima dari peralihan piutang dari harta yang dimiliki oleh debitor yang letaknya ada di luar negeri pada saat diputus pailit. Keberlakuan pasal ini dapat dilaksanakan apabila debitornya dinyatakan pailit oleh pengadilan Niaga, adanya subrogasi kreditor, pihak yang memperoleh pelunasan merupakan kreditor baru, pelunasan tersebut didasarkan pada hasil dari penjualan atau lelang atas harta benda tersebut yang letaknya berada di luar negeri, serta pelunasan dengan harta debitor yang letaknya berada di luar negeri ini merupakan proses yang terpisah

11 Putra, F. M. K. (2014). Eksistensi Kreditor Separatis Sebagai Pemohon Dalam Perkara Kepailitan. Perspektif: Kajian Masalah Hukum dan Pembangunan, 19(1), 1-19. 
dari pelaksanaan hukum kepailitan di Indonesia sehingga tidak dilakukan oleh pihak kurator. ${ }^{12}$

Serta ketentuan berdasarkan Pasal 214 ayat (1) UUK PKPU yang menyebutkan adanya kewajiban untuk memberikan ganti kepada harta pailit sesuai dengan besarnya pelunasan yang diperoleh oleh pihak kreditor yang menerima peralihan piutang. Keberlakuan atas ketentuan ini hanya akan terjadi apabila bahwa debitor diucap pailit oleh pengadilan Niaga, adanya pengalihan piutang, dimungkinkan untuk terjadinya perjumpaan hutang, adanya kompensasi terhadap pihak-pihak yang saling melakukan pengalihan, dan kompensasi hanya dilakukan atas suatu piutang yang salah satunya berada di luar wilayah Indonesia.

Meskipun ketentuan di dalam hukum Indonesia, khususnya di dalam UUK PKPU memberikan peluang adanya pelunasan sisa hutang debitor dengan menggunakan harta yang dimiliki oleh debitor pailit yang letaknya berada di luar negeri, namun ketentuan tersebut tidak bisa serta merta diberlakukan. Hal ini terjadi mengingat bahwa terhadap suatu perkara perdata Internasional harus memandang dan menghormati kaidah-kaidah hukum internasional. ${ }^{13}$ Tidak semua negara memiliki sistem hukum yang sama, sehingga asas-asas yang dianut setiap negara tentu akan berbeda. Terdapat negara-negara yang menganut asas teritorialitas, seperti halnya yang berlaku di Indonesia. Indonesia seperti yang tercermin pada Pasal 436 B.Rv. bahwa atas putusan negara asing tidak memiliki kekuatan eksekusi terhadap Indonesia, sehingga berlaku sebaliknya bahwa putusan oleh pengadilan yang ada di Indonesia juga tidak memiliki kekuatan hukum eksekusi di negara lain.

Ketentuan-ketentuan dalam UUK PKPU tidak mengatur secara jelas mengenai dapat atau tidaknya putusan pailit yang diucapkan oleh pengadilan Niaga memiliki kekuatan eksekusi di negara lain. Meskipun berdasarkan ketentuan di dalam KUHPdt serta didukung dengan ketentuan dalam Pasal 21 UUK PKPU yang pada intinya pada proses kepailitan makan sita umum akan membebani atas keseluruhan kekayaan yang menjadi kepunyaan dari debitor pada saat diucapkannya putusan pailit tersebut maupun yang akan diperoleh, serta pada Pasal 212 UUK PKPU yang memungkinkan bagi kreditor untuk memperoleh pelunasan dengan harta debitor yang berada di luar negeri, tidak serta merta memiliki kekuatan eksekusi akan harta tersebut. Namun perlu diketahui bahwa dalam hukum perdata Internasional putusan pailit suatu negara, termasuk negara Indonesia tidak serta merta dapat diakui dan diterapkan oleh suatu negara karena setiap negara memiliki kedaulatan yang harus dihormati.

\subsection{Upaya Hukum Pelunasan Sisa Utang Debitor Pailit dengan Harta Debitor Pailit yang Berada di Luar Negeri}

Upaya hukum dapat dilakukan oleh kreditor sebagai usaha guna mendapatkan pelunasan piutang yang dimilikinya dapat ditempuh melalui proses kepailitan yang

12 Ratnawati, T. E. (2009). Kajian terhadap Proses Penyelesaian Perkara Kepailitan dan Penundaan Kewajiban Pembayaran Utang di Pengadilan Niaga Jakarta Pusat Kajian terhadap Proses Penyelesaian Perkara Kepailitan dan Penundaan Kewajiban Pembayaran Utang di Pengadilan Niaga Jakarta P. Jurnal Dinamika Hukum, 9(2), 181-190.

13 Mutiara Hikmah, 2007, Aspek-Aspek Hukum Perdata Internasional dalam Perkara-Perkara Kepailitan, Refika Aditama, Jakarta, h. 76. 
bersifat memaksa berdasarkan putusan pailit. Akibat hukum sebagai dampak dengan adanya putusan pailit ini yaitu seluruh harta benda yang dimiliki debitor pailit berada dalam keadaan automatic stay sehingga debitor secara hukum tidak mampu lagi melakukan tindakan atau perbuatan apapun atas harta tersebut. Berdasarkan hukum Internasional, keberlakuan putusan hakim pada suatu negara ada yang bersifat universal atau bersifat teritorial tergantung tentang sistem hukum serta asas apa yang diterapkan suatu negara. Agar suatu putusan hakim memiliki kekuatan hukum dan dapat dieksekusi di negara tersebut, maka putusan tersebut harus mendapatkan pengakuan dari negara tersebut. Terkait adanya harta benda debitor yang berada di luar negeri, maka terhadap perkara kepailitan tersebut dapat dikategorikan sebagai kepailitan lintas batas yang melibatkan unsur-unsur asing. Oleh karenanya, penyelesaian perkara tersebut harus melihat unsur-unsur asing tersebut agar bisa menentukan hukum negara mana yang dapat digunakan dalam penyelesaiannya.

Terhadap perkara kepailitan lintas batas dengan harta debitor berada di luar negeri maka terdapat beberapa cara yang dapat ditempuh sebagai prosedur penyelesaian perkara kepailitan, yakni dengan mengajukan permohonan melalui pengadilan yang ada dinegara letak harta benda debitor, melalui bilateral agreement, diplomatic channel, dan dalam pembaharuan hukum internasional terdapat UNCITRAL Model Law on Cross Border Insolvency with Guide to Enacment. Baik pihak kreditor maupun melalui kurator sebagai wakil dari negara dimungkinkan mengajukan permohonan pengeksekusi dari apa yang menjadi harta debitor yang sudah pailit yang letaknya ada di negara tersebut, namun hal ini memiliki kekurangan yaitu kesulitan agar permohonan tersebut dapat dikabulkan karena terbentur adanya perbedaan hukum dan selain itu apabila menyangkut mengenai harta maka akan memiliki dampak ekonomi terhadap negara letak harta tersebut berada. Maka kemungkinan permohonan tersebut dikabulkan sangatlah kecil, karena setiap negara tentu memiliki kepentingan negaranya masing-masing.

Apabila melalui bilateral agreement, maka harus dipastikan bahwa perjanjian antar negara tersebut menentukan mengenai penyelesaian kepailitan yang melibatkan negara-negara yang ada dalam perjanjian tersebut. Dasarnya perjanjian antar negara ini dibuat memiliki tujuan untuk mengikat atau binding negara dalam menciptakan kerangka kerjasama yang memiliki kekuatan hukum disetiap negara serta memiliki kekuatan memaksa dalam pelaksanannya bagi negara yang terlibat dalam perjanjian tersebut. Perjanjian ini merupakan sebuah bentuk itikad baik (good faith) agar suatu perkara lebih mudah untuk diselesaikan, serta sebagai suatu upaya menjaga agar tidak terjadi perselisihan antar negara dan menjaga kedaulatan negara masing-masing.

Terhadap negara yang tidak memiliki bilateral agreement tetapi memiliki hubungan antar negara yang baik, dapat ditunjukkan dengan diplomatic channel dengan negara tersebut. ${ }^{14}$ Hubungan diplomatik ini diwujudkan dengan saling adanya diplomat dari masing-masing negara. Keberadaan hubungan diplomatik yang baik antar negara merupakan salah satu kelebihan yang dapat digunakan untuk membantu penyelesaian suatu perkara, termasuk penyelesaian perkara lintas batas dengan harta debitor berada

14 Andika, S. R. (2019). PENEGAKAN HUKUM TERHADAP PELAKU TINDAK PIDANA LINTAS NEGARA MELALUI PERJANJIAN EKSTRADISI (SUATU CATATAN MENARIK UNTUK DISKUSI). Era Hukum-Jurnal Ilmiah Ilmu Hukum, 16(2). 
di luar negeri. Peran hubungan diplomatik yakni membantu dalam melakukan komunikasi dengan negara yang dituju, sehingga dengan adanya komunikasi serta prosedur yang disepakati oleh para pihak maka akan mempermudah proses dan eksekusi terhadap benda tersebut.

Selain prosedur-prosedur sebagaimana telah disebutkan di atas, saat ini terdapat pembaharuan hukum internisonal khususnya mengenai kepailitan lintas batas. UNCITRAL Model Law on Cross Border Insolvency with Guide to Enacment sebagai suatu terobosan hukum yang memberikan jalan dan akses untuk melakukan eksekusi terhadap harta debitor pailit yang berada di negara lain, dengan memiliki efek bergesekan antar negara yang sangat kecil. Produk hukum ini mengatur mengenai adanya kerjasama antar negara baik mengenai pengajuan, prosedur, hingga pelaksanaan putusan pailit dan kerjasama antar pengadilan negara yang berperkara.

Khusus mengenai harta debitor yang berada di luar negeri sebagai akibat dari adanya putusan pailit sehingga dieksekusi sebagai alat pelunasan hutang, secara spesifik diatur di dalam Article 21 Paragraph 1 UNCITRAL Model Law on Cross Border Insolvency with Guide to Enactment. Dalam pasal tersebut ditentukan bahwa:

"Setelah pengakuan atas persidangan asing, baik utama maupun non-utama, jika perlu untuk melindungi aset debitor atau kepentingan kreditor, pengadilan dapat, atas permintaan perwakilan asing, memberikan bantuan yang sesuai, termasuk:

(a) meninggalkan dimulainya atau kelanjutan dari tindakan individu atau proses perseorangan tentang aset, hak, kewajiban atau kewajiban debitor, sejauh mereka belum berada di bawah paragraf 1 (a) pasal 20;

(b) eksekusi tetap terhadap aset debitor sejauh itu belum tinggal di bawah ayat 1 (b) pasal 20;

(c) menangguhkan hak untuk mentransfer, membebani atau melepaskan aset debitor sejauh hak ini belum ditangguhkan berdasarkan ayat 1 (c) pasal 20;

(d) menyediakan untuk pemeriksaan saksi, pengambilan bukti pengiriman informasi mengenai aset, urusan, hak kewajiban atau kewajiban debitor;

(e) mempercayakan administrasi atau reaslisasi semua atau sebagian dari aset debitor yang berlokasi di negara ini kepada perwakilan asing dari orang lain yang ditunjuk oleh pengadilan;

(f) bantuan yang diberikan berdasarkan ayat 1 pasal 19;

(g) pemberian bantuan tambahan apa pun yang mungkin tersedia untuk (masukkan gelar seseorang atau badan yang mengelola reorganisasi atau likudiasi di bawah hukum Negara yang memberlakukan) di bawah hukum negara ini."

Berdasarkan ketentuan pada pasal di atas, maka dapat dilihat bahwa adanya kemungkinan untuk melakukan eksekusi terhadap harta debitor pailit yang berada di wilayah hukum negara lain. Eksekusi hanya bisa dilakukan dengan mengikuti ketentuan hukum dan prosedur penyelesaian sesuai dengan hukum nasional dimana letak benda tersebut berada. Keberlakuan ketentuan dalam UNCITRAL Model Law on Cross Border Insolvency with Guide to Enactment merupakan suatu upaya agar hak kreditor tetap dapat dilindungi. Karena dalam hukum internasional yang tertuang dalam UNCITRAL Model Law on Cross Border Insolvency with Guide to Enactment ini menunjukkan bahwa memperoleh pelunasan atas piutang bagi kreditor merupakan suatu hal yang harus dilindungi, karena hal tersebut merupakan suatu hak yang dalam 
kasus kepailitan pastinya hak tersebut sudah langgar oleh pihak debitor. Melalui produk hukum internasional ini sebagai wujud keadilan bagi para pihak yang terlibat perkara kepailitan. Namun tetap harus diingat bahwa keberlakuan UNCITRAL Model Law on Cross Border Insolvency with Guide to Enactment hanya bisa dilakukan terhadap negara-negara yang telah menundukkan diri pada ketentuan ini dengan cara meratifikasinya. Dengan kata lain terhadap negara yang tidak meratifikasi UNCITRAL Model Law on Cross Border Insolvency with Guide to Enactment, maka penyelesaiaan perkara kepailitan hanya dapat ditempuh dengan mengajukan permohonan melalui pengadilan yang ada dinegara letak harta benda debitor, melalui bilateral agreement, diplomatic channel.

\section{Kesimpulan}

Berdasarkan hasil dari pemaparan sebelumnya, maka dapat ditarik kesimpulan sebagai berikut :

1. Mengingat adanya asas yang dianut suatu negara, maka dapat dikatakan bahwa ketentuan dalam UUK PKPU memungkinkan bagi kreditor untuk memperoleh pelunasan dengan harta yang ada di luar negeri, namun dalam hal eksekusinya tetap harus memperhatikan sistem negara serta asas yang dianut oleh negara dimana letak harta benda tersebut berada.

2. Terdapat beberapa upaya yang dapat dilakukan guna memperoleh pelunasan dengan harta benda debitor pailit yang berada di luar negeri, yakni dengan cara mengajukan permohonan melalui pengadilan yang ada dinegara letak harta benda debitor, melalui bilateral agreement, diplomatic channel, dan menggunakan UNCITRAL Model Law on Cross Border Insolvency with Guide to Enacment. Dalam penyelesaiannya tentu akan lebih mudah menggunakan UNCITRAL Model Law on Cross Border Insolvency with Guide to Enacment, tetapi hingga saat ini tidak semua negara di dunia meratifikasi sehingga terhadap negara yang tidak meratifikasi ketentuan ini tidak bisa digunakan.

\section{Ucapan Terima Kasih (Acknowledgments)}

Saya panjatkan rasa puja serta puji syukur kepada Tuhan Yang Maha Esa karenaNya lah penulis mampu untuk menyelesaiakan penulisan jurnal ini yang mengangkat judul, "Penyelesaian Perkara Kepailitan dengan Harta Pailit Berada di Luar Negeri". Penulis berharap agar dengan keberadaan jurnal ini dapat bermanfaat bagi pembacanya.

Dalam tahapan pembuatan jurnal ini, tentu penulisan menemukan berbagai hambatan, oleh karenanya penulisan hendak mengucapkan terima kasih kepada semua pihak yang telah memberikan dorongan sebagai support dan semangat sehingga penulis dapat menyelesaikan penulisan jurnal ini. 


\section{Daftar Pustaka}

\section{$\underline{\text { Buku }}$}

Mutiara Hikmah, 2007, Aspek-Aspek Hukum Perdata Internasional dalam Perkara-Perkara Kepailitan, Refika Aditama, Jakarta.

\section{Jurnal}

Amalia, J. (2019). URGENSI IMPLEMENTASI UNCITRAL MODEL LAW ON CROSSBORDER INSOLVENCY DI INDONESIA: STUDI KOMPARASI HUKUM KEPAILITAN LINTAS BATAS INDONESIA DAN SINGAPURA. Jurnal Hukum Bisnis Bonum Commune, 2(2), 162-172.

Andika, S. R. (2019). PENEGAKAN HUKUM TERHADAP PELAKU TINDAK PIDANA LINTAS NEGARA MELALUI PERJANJIAN EKSTRADISI (SUATU CATATAN MENARIK UNTUK DISKUSI). Era Hukum-Jurnal Ilmiah Ilmu Hukum, 16(2).

Asnil, D. M. (2018). UNCITRAL Model Law on Cross Border Insolvency Sebagai Model Pengaturan Kepailitan Lintas Batas Indonesia dalam Integrasi Ekonomi ASEAN. Undang: Jurnal Hukum, 1(2), 323-346.

Budiono, D. (2019). Analisis Pengaturan Hukum Acara Kepailitan dan Penundaan Kewajiban Pembayaran Utang. Jurnal Hukum Acara Perdata ADHAPER, 4(2), 109127.

Hardjaloka, L. (2015). Kepailitan Lintas Batas Perspektif Hukum Internasional Dan Perbandingannya Dengan Instrumen Nasional Di Beberapa Negara. Yuridika, 30(3), 480-504.

Makmur, S. (2018). Kepastian Hukum Kepailitan Bagi Kreditur dan Debitur Pada Pengadilan Niaga Indonesia. Mizan: Journal of Islamic Law, 4(2).

Putra, F. M. K. (2014). Eksistensi Kreditor Separatis Sebagai Pemohon Dalam Perkara Kepailitan. Perspektif: Kajian Masalah Hukum dan Pembangunan, 19(1), 1-19.

Ratnawati, T. E. (2009). Kajian terhadap Proses Penyelesaian Perkara Kepailitan dan Penundaan Kewajiban Pembayaran Utang di Pengadilan Niaga Jakarta Pusat Kajian terhadap Proses Penyelesaian Perkara Kepailitan dan Penundaan Kewajiban Pembayaran Utang di Pengadilan Niaga Jakarta P. Jurnal Dinamika Hukum, 9(2), 181-190.

Retnaningsih, S. (2018). Perlindungan Hukum Terhadap Debitor Pailit Individu Dalam Penyelesaian Perkara Kepailitan Di Indonesia. ADHAPER: Jurnal Hukum Acara Perdata, 3(1), 1-16. 
Wijayanta, T. (2014). Asas Kepastian Hukum, Keadilan dan Kemanfaatan dalam Kaitannya dengan Putusan Kepailitan Pengadilan Niaga. Jurnal Dinamika Hukum, 14(2), 216-226.

\section{Peraturan Perundang-Undangan}

Kitab Undang-Undang Hukum Perdata;

Undang-Undang Nomor 37 Tahun 2004 tentang Kepailitan dan Penundaan Kewajiban Pembayaran Utang, Lembaran Negara Republik Indonesia Tahun 2004 Nomor 131, Tambahan Lembaran Negara Republik Indonesia Nomor 4443; dan

United Nations Commission on International Trade Law (UNCITRAL) Model Law in Cross Border Insolvency with Guide to Enactment. 